\title{
Changes in content and localization of proteins phosphorylated at tyrosine, serine and threonine residues during ram sperm capacitation and acrosome reaction
}

\author{
Patricia Grasa ${ }^{1}$, Carmen Colas ${ }^{1}$, Margarita Gallego ${ }^{2}$, Luís Monteagudo ${ }^{3}$, Teresa Muiño-Blanco ${ }^{1}$ \\ and José Álvaro Cebrián-Pérez ${ }^{1}$ \\ ${ }^{1}$ Department of Biochemistry and Molecular and Cell Biology, ${ }^{2}$ Animal Pathology and Anatomy and ${ }^{3}$ Embryology and \\ Genetics, School of Veterinary Medicine, University of Zaragoza, 50013 Zaragoza, Spain
}

Correspondence should be addressed to T Muiño-Blanco; Email: muino@unizar.es

P Grasa is now at Department of Pharmacology, University of Oxford, Oxford, UK

$\mathrm{P}$ Grasa and C Colas contributed equally to this article

T Muiño-Blanco and J Á Cebrián-Pérez share senior co-authorship

\begin{abstract}
Previously, we reported the involvement of tyrosine phosphorylation in events that lead to ram sperm capacitation. In this study, we carried out a comparative analysis of the localization of tyrosine, serine and threonine phosphoproteins in different functional stages of ram spermatozoa (after the swim-up procedure, in vitro capacitation, and ionophore-induced acrosome reaction) by immunofluorescence, immunocytochemistry and confocal microscopy. Capacitation increased protein tyrosine, serine and threonine phosphorylation whereas the induction of the acrosome reaction resulted in significantly decreased phosphorylation, mainly in those proteins that increased following capacitation. Control samples showed tyrosine-phosphorylated proteins restricted to the head, mainly distributed at the equatorial region with some cells also displaying an acrosomal and/or post-acrosomal localization. In vitro capacitation promoted both tail and acrosome phosphorylation, and the acrosome reaction induced the loss of labeling on the acrosome and the subsequent increase in the post-acrosomal region and flagellum. The preferential localization of serine- and threonine-phosphorylated proteins in the equatorial and acrosomal regions found in control samples changed during capacitation, which induced tail phosphorylation in a sequential manner. After the acrosome reaction, the labeling of both phosphoamino acids decreased in the acrosome and increased in the post-acrosome. The obtained results were proved by two immunodetection techniques and strengthened by confocal microscopy, and indicate that changes in phosphorylated proteins during capacitation and acrosome reaction of ram spermatozoa may have physiological significance in consolidating certain phosphorylated proteins to specific sperm regions involved in acrosomal exocytosis and zona pellucida recognition, binding and penetration.

Reproduction (2009) 137 655-667
\end{abstract}

\section{Introduction}

After ejaculation, mammalian spermatozoa are unable to fertilize the egg. They become gradually fertilization competent after a complex set of modifications during a finite period of residence in the female reproductive tract. During this time, the spermatozoa undergo a remodeling process known as capacitation, which is characterized by a series of profound biochemical and biophysical transformations by which the spermatozoa acquire the fertilizing ability (Yanagimachi 1994). The molecular events associated with capacitation are involved in the induction of hyperactivation, characterized by changes in sperm motility patterns (Yanagimachi 1994, Suarez 1996) and acrosome reaction (Visconti et al. 2002). The acrosome reaction is a specialized exocytotic event consisting of the fenestration and fusion of the outer acrosomal membrane and the overlying plasma membrane at multiple sites (Yanagimachi 1994), which results in both the release of hydrolytic enzymes and in the exposure of new membrane domains, both of which are essential for the fertilization process. These two processes, capacitation and acrosome reaction, are regulated by intracellular signals and associated with protein phosphorylation (Aitken et al. 1995, Burks et al. 1995, Baldi et al. 1996, Visconti \& Kopf 1998, Visconti et al. 2002, Naz \& Rajesh 2004, Liguori et al. 2005, O'Flaherty et al. 2006a). However, the precise mechanisms involved in sperm capacitation and acrosomal exocytosis are still not fully understood.

Protein phosphorylation is a post-translational modification of proteins that allows the cell to control many 
cellular processes such as transduction of extracellular signals and intracellular transport (Ullrich \& Schlessinger 1990, Johnson \& Barford 1993, Johnson \& O'Reilly 1996). Mature spermatozoa are highly specialized cells with specific functions directed to fertilization that are compartmentalized within specific subcellular regions. Post-translational protein phosphorylation plays a key role in sperm function and regulates processes such as capacitation, hyperactivation motility and the acrosome reaction. Signal transduction involves reversible phosphorylations regulated through protein kinases and phosphatases, which occurs predominantly on serine, threonine and tyrosine residues (Johnson \& Barford 1993, Wera \& Hemmings 1995). However, to date, only a few sperm-phosphorylated proteins have been identified and the knowledge of sperm tyrosine kinases and other seronine/threonine kinases remains limited.

In most species studied, sperm tyrosine-phosphorylated proteins are mainly located at the flagellum during the course of capacitation and fertilization (Carrera et al. 1996, Leclerc et al. 1997, Mahony \& Gwathmey 1999, Si \& Okuno 1999, Lewis \& Aitken 2001, Urner et al. 2001, Petrunkina et al. 2003, Pommer et al. 2003, Sakkas et al. 2003), and the presence of tyrosine phosphorylation in the principal piece has been correlated with the acquisition of hyperactivated motility (Nassar et al. 1999, Si \& Okuno 1999, Petrunkina et al. 2003). In addition, a capacitation-associated redistribution of phosphotyrosine residues to the acrosome has been reported in boars (Petrunkina et al. 2001, Tardif et al. 2001), bulls (Cormier \& Bailey 2003) and buffalo (Roy \& Atreja 2008), and specific phosphotyrosine proteins localized over the acrosomal region have been postulated to be involved in the zona pellucida interaction and/or fusion events (Leyton \& Saling 1989, Naz et al. 1991, Ficarro et al. 2003, Dube et al. 2005).

Although very little is known about serine/threonine phosphorylation, several studies have shown a timedependent increase in serine and/or threonine phosphorylation during sperm capacitation in species such as humans (Naz 1999, O'Flaherty et al. 2004), hamsters (Jha \& Shivaji 2002 b), boars (Harayama 2003) and mice (Jha et al. 2006). Besides the well-characterized protein kinase A (PKA), other Ser/Thr kinases and the ERKs have been involved in sperm capacitation and acrosome reaction (Luconi et al. 1998, du Plessis et al. 2001, de Lamirande \& Gagnon 2002, Liguori et al. 2005). More recently, specific targets to PKA phosphorylation has been established in human (O'Flaherty et al. 2004, Moseley et al. 2005) and boar sperm (Harrison 2004). Likewise, a cAMP-independent serine/threonine phosphorylation has been described. Thus, an ecto-cAMPindependent protein kinase has been located on the outer surface of mature goat spermatozoa (Maiti et al. 2004) and a proline-directed serine/threonine phosphorylation associated to mouse sperm capacitation has been reported (Jha et al. 2006).
In a previous report, we demonstrated an increase in protein tyrosine phosphorylation associated to capacitation in ram spermatozoa (Perez-Pe et al. 2002), and that the CAMP-PKA pathway is partially implicated in ram sperm capacitation (Grasa et al. 2006). Therefore, our first objective was to determine whether serine and threonine phosphorylation is involved in events that lead to ram sperm capacitation. In addition, we also investigated the protein phosphorylation associated to the acrosome reaction induced by calcium ionophore A23187. Furthermore, we analyzed the localization of serine, threonine and tyrosine phosphoproteins associated to different functional stages of ram spermatozoa (after the swim-up procedure, in vitro capacitation, and acrosome reaction) by means of immunocytological techniques.

\section{Results}

\section{Protein phosphorylation associated with in vitro capacitation and acrosome reaction}

In a previous study, we reported that the incubation of fresh ram spermatozoa in capacitating conditions is associated to an increase in protein tyrosine phosphorylation (Grasa et al. 2006). In this study, we investigated whether ram sperm capacitation induced in vitro is related to serine/threonine phosphorylation, as well as the profile of phosphorylated proteins associated to the ionophore-induced acrosome reaction. Evaluation of the physiological state by chlortetracycline (CTC)/ethidium homodimer 1 (EthD-1) staining (Fig. 1) showed a significant increase $(P<0.001)$ in the percentage of capacitated sperm after $4 \mathrm{~h}$ of incubation in capacitating conditions, compared with control samples $(0 \mathrm{~h})$. Likewise, a significant increase $(P<0.001)$ in the acrosomereacted (AR) CTC-pattern was achieved in samples stimulated with calcium ionophore (Fig. 1).

Figure 2 shows the phosphoprotein profile of control, capacitated and AR samples. Several proteins were

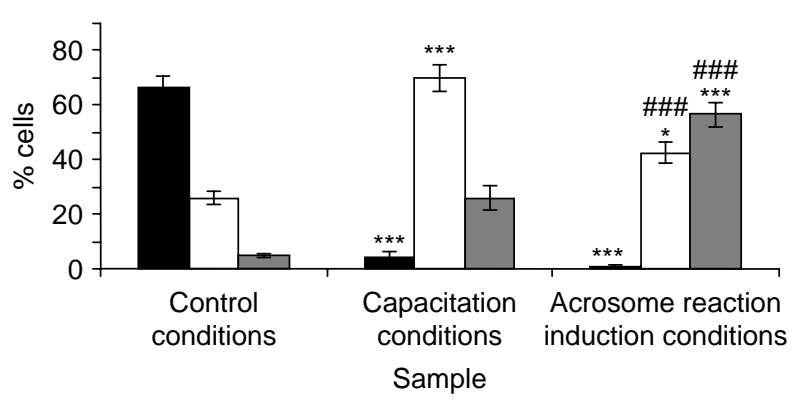

Figure 1 Assessment of the capacitation state by CTC/EthD-1 staining of ram spermatozoa obtained by swim-up at $0 \mathrm{~h}$ (control samples), incubated $4 \mathrm{~h}$ in capacitation conditions at $39{ }^{\circ} \mathrm{C}$ under $100 \%$ humidity and $5 \% \mathrm{CO}_{2}$ (capacitated samples), and treated with $3 \mu \mathrm{M}$ calcium ionophore $\mathrm{A} 23187$ for $1 \mathrm{~h}$ at $39^{\circ} \mathrm{C}$ (acrosome-reacted samples). Percentage of cells: black bars, not capacitated; white bars, capacitated; gray bars, acrosome reacted. Mean values \pm s.E.M. $(n=5)$. Significant differences related to control samples: ${ }^{*} P<0.05$; $* * * P<0.001$. Significant differences related to capacitated samples: ${ }^{\# \#} P<0.001$. 

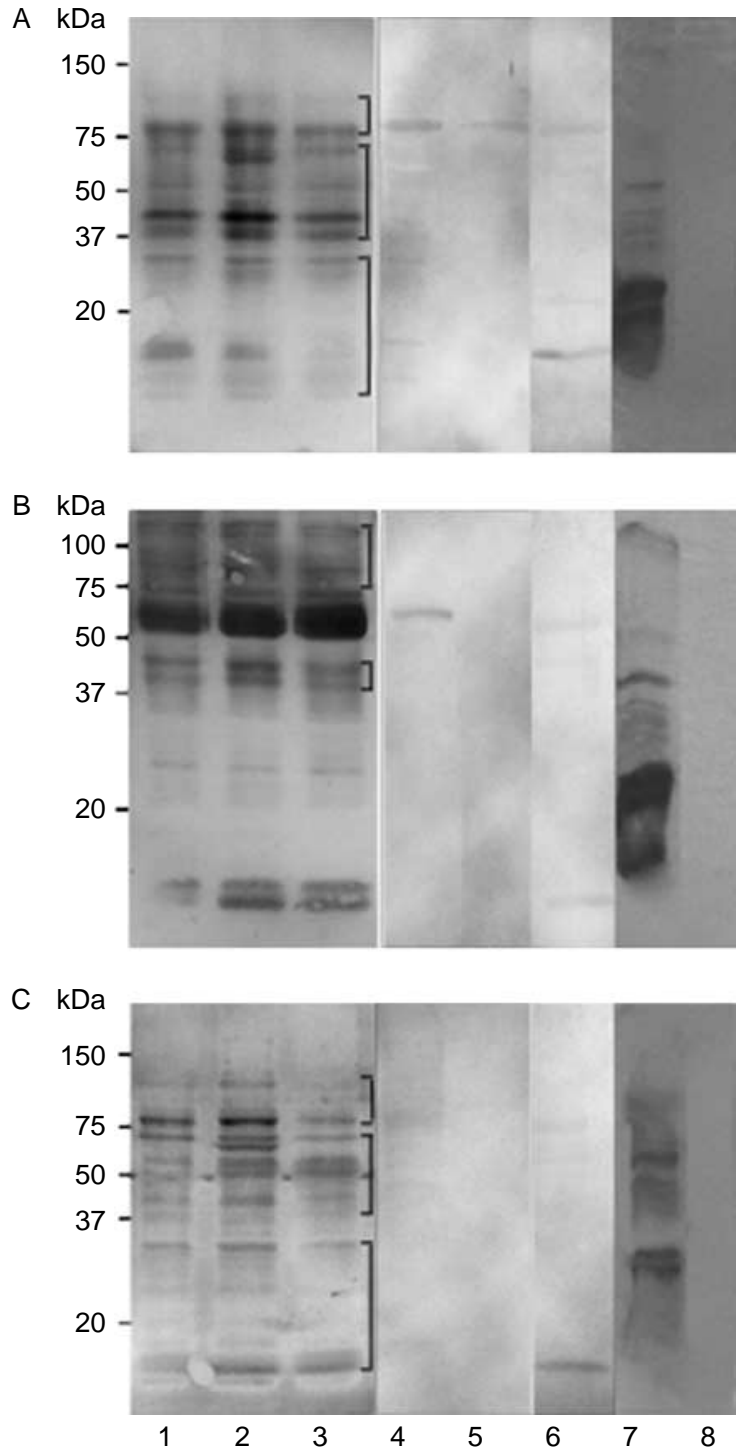

Figure 2 Immunoblot analysis of the effect of the capacitation and the A23187-induced acrosome reaction on ram sperm protein phosphorylation in tyrosine $(A)$, serine $(B)$ and threonine $(C)$ residues. Sperm were obtained by swim-up (control samples, lane 1), incubated in capacitation conditions for $4 \mathrm{~h}$ at $39{ }^{\circ} \mathrm{C}$ under $100 \%$ humidity and $5 \%$ $\mathrm{CO}_{2}$ (capacitated samples, lane 2), and treated with $3 \mu \mathrm{M}$ calcium ionophore $\mathrm{A} 23187$ for $1 \mathrm{~h}$ at $39^{\circ} \mathrm{C}$ (acrosome-reacted samples, lane 3). Binding of antibody in the presence of $100 \mu \mathrm{g} / \mathrm{ml}$ (lane 4) and $500 \mu \mathrm{g} / \mathrm{ml}$ (lane 5) of phosphotyrosine, $25 \mu \mathrm{g} / \mathrm{ml}$ (lane 4) and $50 \mu \mathrm{g} / \mathrm{ml}$ (lane 5) of phosphoserine, and $50 \mu \mathrm{g} / \mathrm{ml}$ (lane 4) and $100 \mu \mathrm{g} / \mathrm{ml}$ (lane 5) of phosphothreonine, after incubation with $23 \mathrm{U}$ alkaline phosphatase (lane 6). Positive (casein, lane 7) and negative (FurA of Anabaena sp. PPC7 120, lane 8) controls are shown. Proteins extracted from $10^{7}$ spermatozoa were analyzed by western blotting, as described under M\&M. The experiment was performed three times and representative images are shown.

already phosphorylated at tyrosine, serine and threonine residues in control samples (Fig. 2A-C), as we have already reported at tyrosine (Perez-Pe et al. 2002, Grasa et al. 2006). We confirmed that in vitro capacitation promoted a significant increase in the content of some bands phosphorylated at tyrosine (Table 1) as reported previously (Grasa et al. 2006).

Regarding phosphorylation at serine residues, three molecular weight regions were distinguished in western blots of control samples (Fig. 2B). Three bands at the high molecular mass region (84-120 kDa), four bands at the 40-70 kDa molecular mass region (one thicker of $55 \mathrm{kDa}$ and three of $\sim 70,45$ and $40 \mathrm{kDa}$ ), and another two weak bands of low molecular mass $(<30 \mathrm{kDa})$. In vitro capacitation promoted a significant increase in the detected bands at the 84-120 kDa and 45-40 kDa molecular mass regions (Table 1 ).

The anti-phosphothreonine antibody specifically recognized a set of phosphoproteins in control samples (Fig. 2C). At least eight protein bands were detected, two bands in the 84-120 kDa molecular mass region, (a faint band of $\sim 120 \mathrm{kDa}$ and another of $84 \mathrm{kDa}$ ), five bands ranged from 40 to $70 \mathrm{kDa}$ molecular masses, and another of $\sim 30 \mathrm{kDa}$. Densitometric quantification revealed that capacitation resulted in a significantly higher intensity of the bands in these three molecular weight regions (Table 1 ).

The ionophore-induced acrosome reaction was accompanied by a significant decrease in the intensity of phosphorylation for all three residues (Table 1; Fig. 2, lane 3 ). It is worth pointing out that certain bands of phosphotyrosine- (84-120, 40-70, and <30 kDa molecular mass regions, Fig. 2A, lane 3$)$, serine- $(40-45 \mathrm{kDa}$ and $84-120 \mathrm{kDa}$ molecular mass regions, Fig. 2B, lane 3) and threonine- (84-120, 40-70, and $<30 \mathrm{kDa}$ molecular mass regions, Fig. 2C, lane 3) phosphorylated proteins with increased intensity after capacitation showed a significantly lower intensity labeling after the acrosome reaction.

Incubation of membranes with phosphotyrosine, phosphoserine, or phosphothreonine proved the

Table 1 Densitometric analysis of the of phosphorylation signal at tyrosine (Tyr), serine (Ser) and threonine (Thr) residues in control (CT), capacitated (CA) and acrosome-reacted (AR) sperm samples.

\begin{tabular}{|c|c|c|c|c|}
\hline & \multirow[b]{2}{*}{$\begin{array}{l}\text { Molecular } \\
\text { region }\end{array}$} & \multicolumn{3}{|c|}{ Sample } \\
\hline & & $\mathrm{CT}$ & CA & $\mathrm{AR}$ \\
\hline Tyr & $\begin{array}{l}84-120 \\
40-70 \\
\leq 30\end{array}$ & $\begin{array}{r}104.3 \pm 7.7^{\mathrm{b}} \\
143.7 \pm 5.1^{\mathrm{b}} \\
92.7 \pm 1.8^{\mathrm{b}}\end{array}$ & $\begin{array}{l}138.7 \pm 9.5^{\mathrm{a}} \\
170.7 \pm 8.1^{\mathrm{a}} \\
110.6 \pm 5.8^{\mathrm{a}}\end{array}$ & $\begin{array}{c}94.0 \pm 12.8^{\mathrm{b}} \\
130.8 \pm 11.6^{\mathrm{b}} \\
85.3 \pm 4.6^{\mathrm{b}}\end{array}$ \\
\hline Ser & $\begin{array}{l}84-120 \\
40-45\end{array}$ & $\begin{array}{r}99.0 \pm 4.5^{\mathrm{b}} \\
108.3 \pm 2.4^{\mathrm{b}}\end{array}$ & $\begin{array}{l}115.1 \pm 3.5^{\mathrm{a}} \\
122.1 \pm 4.1^{\mathrm{a}}\end{array}$ & $\begin{array}{l}100.1 \pm 4.5^{\mathrm{b}} \\
107.9 \pm 2.9^{\mathrm{b}}\end{array}$ \\
\hline Thr & $\begin{array}{l}84-120 \\
40-70 \\
\leq 30\end{array}$ & $\begin{array}{c}107.4 \pm 3.2^{\mathrm{b}} \\
122.9 \pm 12.1^{\mathrm{b}} \\
89.1 \pm 7.9^{\mathrm{b}}\end{array}$ & $\begin{array}{l}122.7 \pm 2.0^{\mathrm{a}} \\
157.7 \pm 2.7^{\mathrm{a}} \\
117.6 \pm 6.2^{\mathrm{a}}\end{array}$ & $\begin{array}{r}96.9 \pm 7.1^{\mathrm{b}} \\
114.7 \pm 6.9^{\mathrm{c}} \\
82.6 \pm 10.6^{\mathrm{b}}\end{array}$ \\
\hline
\end{tabular}

Results indicate the phosphorylation signal (area $\times$ intensity) of different molecular weight regions relative to the total phosphorylation signal $(100 \%)$ obtained in every case. Mean values \pm s.E.M. $(n=3)$. Different superscripts in rows indicate significant differences. ${ }^{\mathrm{a}-\mathrm{b}} P<0.05$; ${ }^{\mathrm{a}-\mathrm{c}} P<0.01$. 

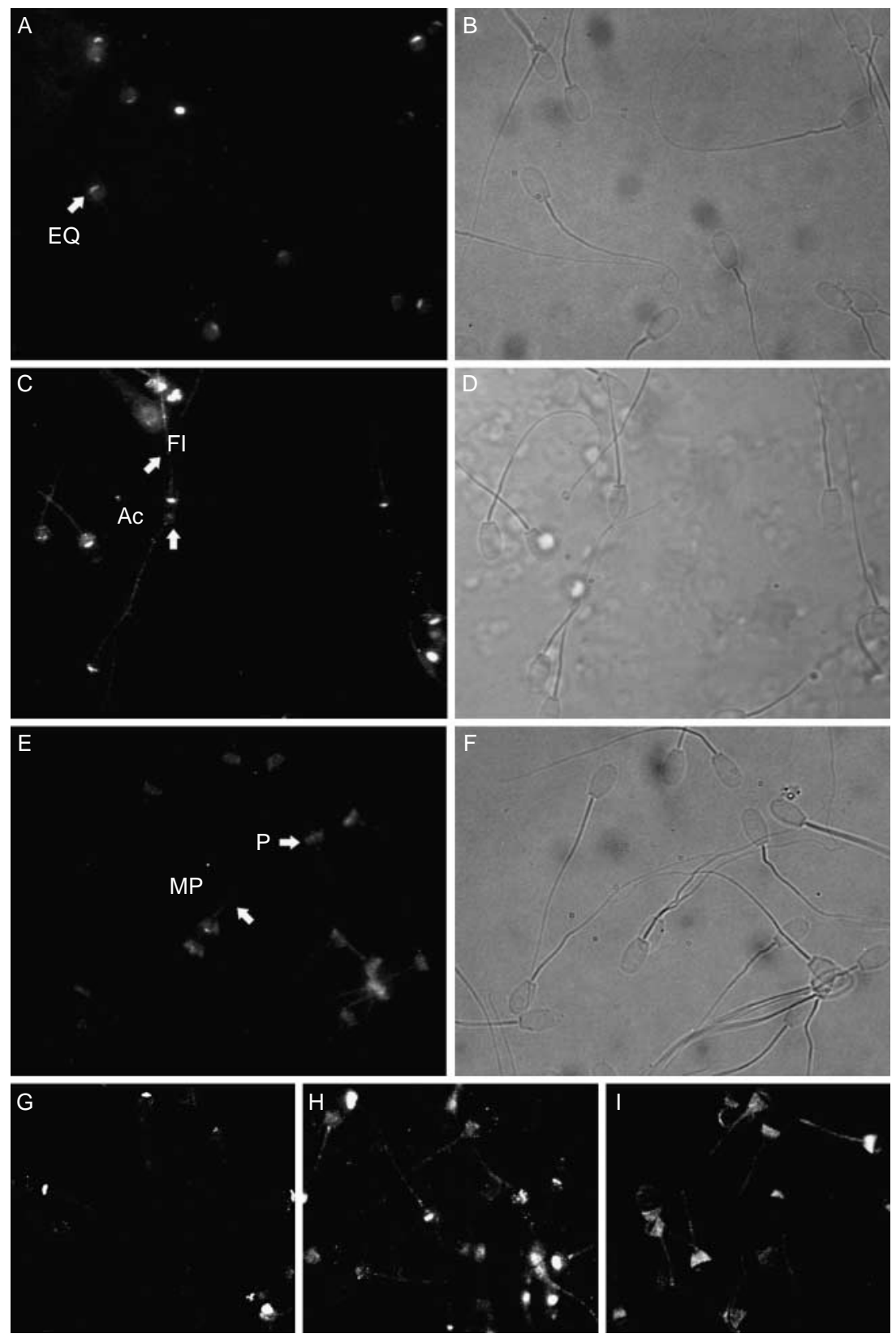

Figure 3 Indirect immunofluorescence localization of phosphotyrosine proteins in control $(0 \mathrm{~h}, \mathrm{~A}-\mathrm{B})$, capacitated (4 h, C-D) and acrosome-reacted (E-F) ram spermatozoa using monoclonal anti-phosphotyrosine antibody and FITC-conjugated chicken anti-mouse IgG. Panels A, C and E correspond to fluorescence images. Panels B, D and $\mathrm{F}$ correspond to their respective bright field. Panels $\mathrm{G}, \mathrm{H}$ and I show representative confocal microscopy images of control, capacitated and acrosome-reacted samples respectively. The arrows indicate different domains with specific phosphorylation: $E Q$, equatorial region; $A c$, acrosome; $\mathrm{P}$, post-acrosome; MP, middle piece; and $\mathrm{Fl}$, flagellum. Magnification $1000 \times$. specificity of each antibody as the binding was eliminated in the presence of the competing agents. Different concentrations of the three phosphoamino acids were assayed, and the obtained results are shown in Fig. 2 (lanes 4, 5).

To prove that these protein bands are phosphorylated, sperm protein samples were treated with alkaline phosphatase for removing the phosphate groups. As shown in Fig. 2 (lane 6), most proteins were fully dephosphorylated as reactivity disappeared, and only two bands were barely visible by incubating with the primary mouse monoclonal anti- phosphotyrosine, phosphoserine, or phosphothreonine antibody.

\section{Immunolocalization of phosphorylated proteins in ram spermatozoa during in vitro capacitation and acrosome reaction}

The localization of tyrosine-, serine- and threoninephosphorylated proteins and their modifications according to the functional state of ram spermatozoa were analyzed by indirect immunofluorescence and confocal microscopy, and confirmed by immunocytochemistry. Phosphoresidues were associated with specific sperm domains, and we were able to distinguish different sperm subpopulations according to their surface distribution (Figs 3, 4 and 5). The mean percentage of each subpopulation in control, capacitated and AR samples 

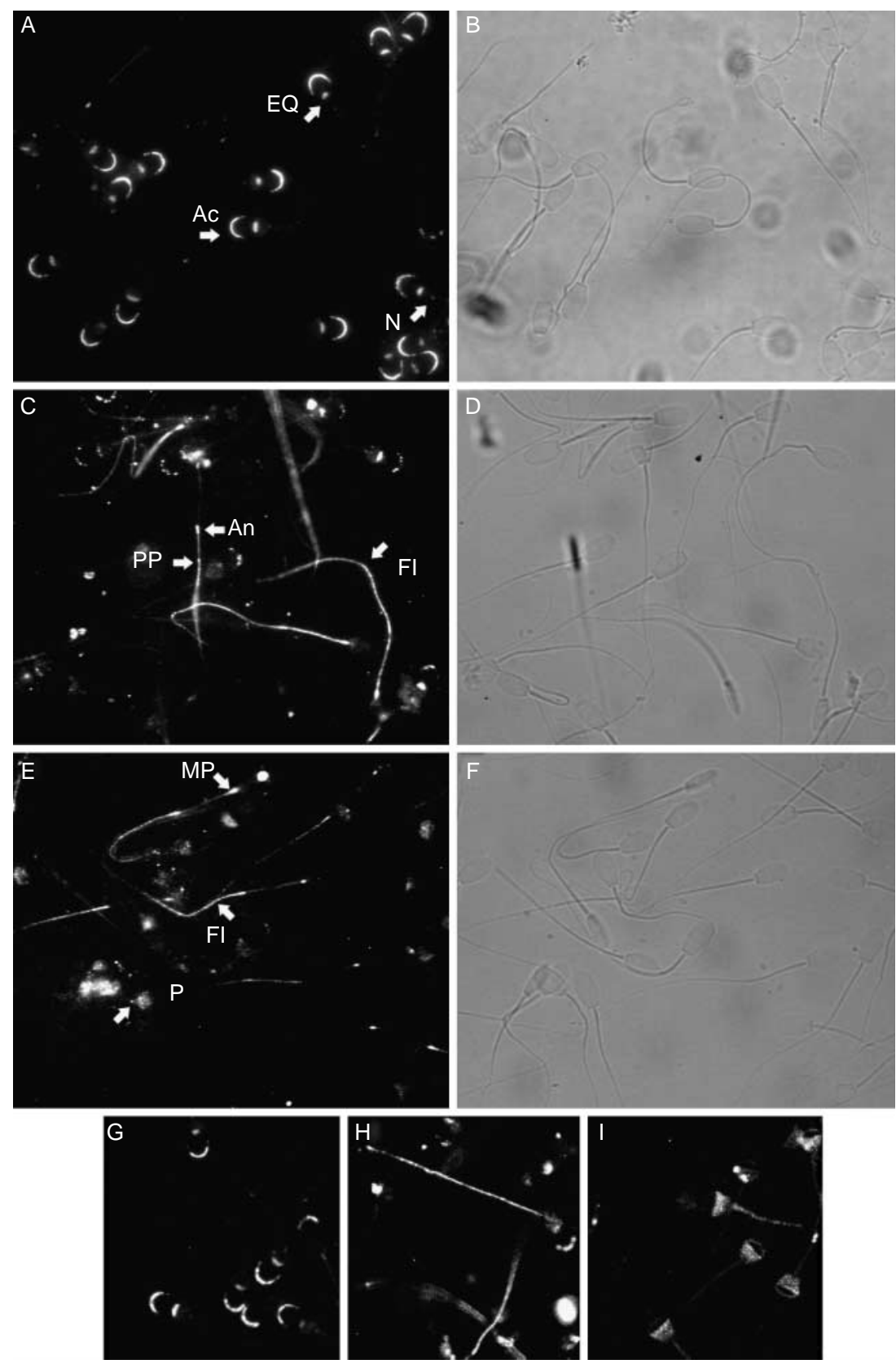

Figure 4 Indirect immunofluorescence localization of phosphoserine proteins in control $(0 \mathrm{~h}$, A-B), capacitated (4 h, C-D) and acrosomereacted $(\mathrm{E}-\mathrm{F})$ ram spermatozoa using monoclonal anti-phosphoserine antibody and FITC-conjugated chicken anti-mouse IgG. Panels $\mathrm{A}, \mathrm{C}$ and $\mathrm{E}$ correspond to fluorescence images. Panels B, D and $\mathrm{F}$ correspond to their respective bright field. Panels G, H and I show representative confocal microscopy images of control, capacitated and acrosome-reacted samples respectively. The arrows indicate different domains with specific phosphorylation: $\mathrm{EQ}$, equatorial region; $\mathrm{Ac}$, acrosome; N, neck; An, annulus; P, post-acrosome; MP, middle piece; PP, principal piece; and $\mathrm{Fl}$, flagellum. Magnification $1000 \times$. was assessed. Less than $10 \%$ of cells were unstained for all three residues and no significant differences were found between samples. These results were highly specific because samples processed with the secondary antibody only showed no signaling (Fig. 6A and B), and replacing the antiserum with preimmune serum abolished protein detection (Fig. 6C and D). Likewise, pre-incubation of each primary antibody with phosphotyrosine, phosphoserine and phosphothreonine respectively, showed no reactivity in any case (Fig. 7). For a better analysis, the different sperm patterns of tyrosine-, serine- and threonine-phosphorylated proteins were grouped in six categories (Fig. 8).
In control samples, tyrosine phosphoproteins were located on the sperm head (Fig. 3A), predominantly at the equatorial segment $(80.62 \%$, Fig. $8 \mathrm{~A})$, either with or without a faint signal in the acrosomal and/or postacrosomal region. In vitro capacitation promoted phosphorylation both in tail $(P<0.001$, Fig. $8 \mathrm{~A})$, with differences in length and intensity from the anterior midpiece and principal piece to the whole flagellum, and punctate staining at the anterior portion of the acrosome (Fig. 3C). Finally, in A23187-stimulated samples, changes in phosphotyrosine protein localization towards the post-acrosomal and midpiece regions were found (Figs $3 \mathrm{E}$ and $8 \mathrm{~A}$ ). Therefore, 

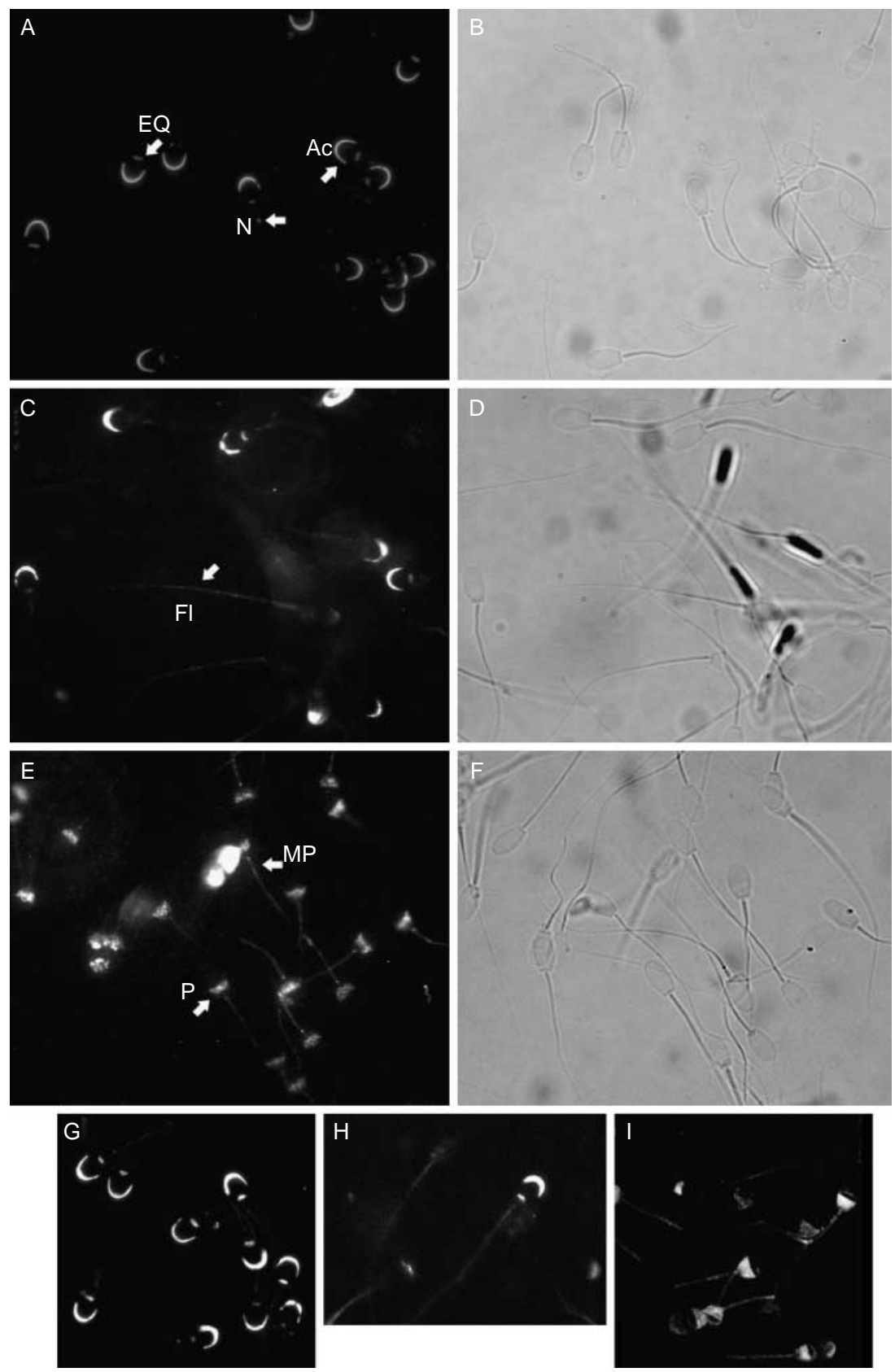

Figure 5 Indirect immunofluorescence localization of phosphothreonine proteins in control (0 h, A-B), capacitated (4 h, C-D) and acrosomereacted $(\mathrm{E}-\mathrm{F})$ ram spermatozoa using monoclonal anti-phosphothreonine antibody and FITC-conjugated chicken anti-mouse IgG. Panels $A, C$ and E correspond to fluorescence images. Panels B, D and $\mathrm{F}$ correspond to their respective bright field. Panels G, H and I show representative confocal microscopy images of control, capacitated and acrosome-reacted samples respectively. The arrows indicate different domains with specific phosphorylation: EQ, equatorial region; $\mathrm{Ac}$, acrosome; N, neck; P, post-acrosome; MP, middle piece; and $\mathrm{Fl}$, flagellum. Magnification $1000 \times$. acrosomal exocytosis resulted in a significant loss of the acrosomal localization of phosphotyrosine proteins (69.96\% in capacitated samples versus $14.38 \%$ in AR samples, $P<0.001)$. The confocal analysis confirmed these observations (Fig. 3G-I) and $z$-axis series images showed a subcellular localization of different tyrosine phosphoproteins (images not shown).

The distribution of proteins phosphorylated at serine and/or threonine residues was similarly analyzed. Before incubation, phosphoserine proteins were mainly distributed both in the acrosome and equatorial regions $(75.53 \%$, Fig. $8 \mathrm{~B})$, with or without a faint signal at the neck. This immunopattern was characterized by a bright arch-like staining at the equatorial segment as well as a strong punctate signal forming a band in the apical ridge of the acrosome (Fig. 4A). In addition, $24.33 \%$ of cells displayed fluorescence in the tail, mainly restricted to the anterior part of the midpiece and principal piece. Capacitation promoted serine phosphorylation labeling in the flagellum $(P<0.01$, Fig. $4 \mathrm{C})$ simultaneously with a decrease in the intensity and percentage of cells with acrosomal localization $(85.56 \%$ in control versus $44.19 \%$ in capacitated samples, $P<0.001)$. Tail fluorescence ranged from a partial signal located at the neck, annulus and principal piece to a strong staining in the entire flagellum. It is noteworthy that phosphorylation 

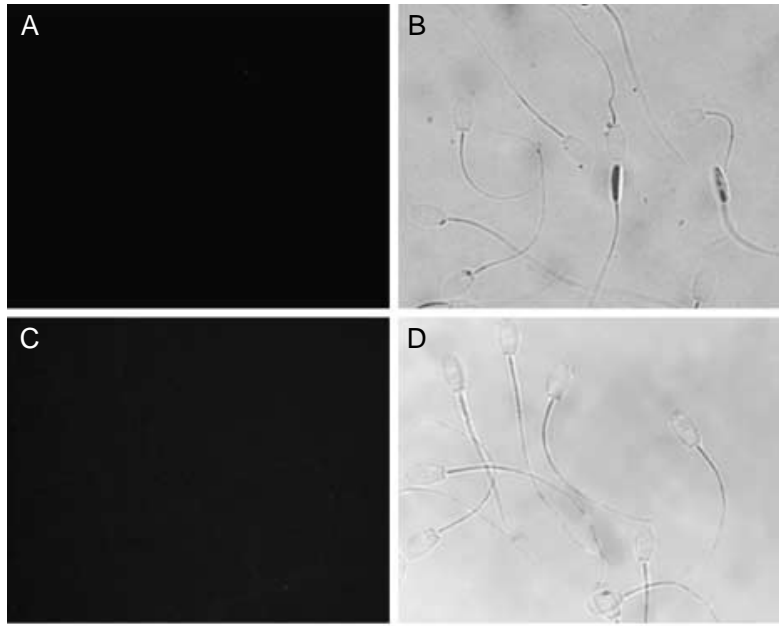

E
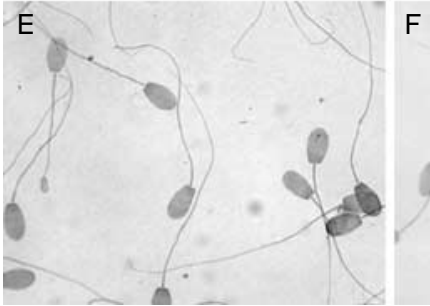

$\mathrm{F}$

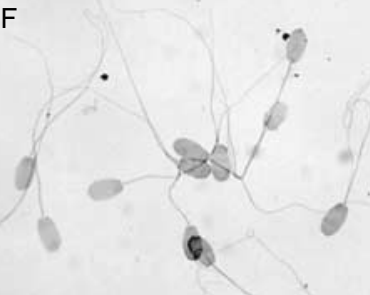

Figure 6 Negative controls of indirect immunofluorescence (A-D) and immunocytochemistry (E, F). Samples incubated with only the secondary antibody (panels A, B and E). Samples incubated with preimmune serum instead of the primary antibody (panels $C, D$ and $F$ ). Paired epifluorescent $(A, C)$ and bright-field $(B, D)$ pictures respectively are shown. Magnification $1000 \times$.

in the whole flagellum was often associated with the loss of the acrosomal and equatorial distributions with $44.53 \%$ of sperm displaying labeling only in the tail $(P<0.001)$. After inducing the acrosome reaction, only $17.8 \%$ of cells showed a certain signal in the acrosome, and phosphoserine protein signaling increased in the post-acrosomal region, with $44.75 \%$ of cells also presenting tail reactivity (Figs $4 \mathrm{E}$ and $8 \mathrm{~B}$ ). These results were confirmed by confocal microscopy (Fig. 4G-I).

When anti-phosphothreonine antibody was used, control samples also showed fluorescence over the acrosomal and equatorial regions $(80.62 \%)$, with $(30.58 \%)$ or without $(50.04 \%)$ punctate labeling at the connection piece (Figs $5 \mathrm{~A}$ and $8 \mathrm{C}$ ). A total of $80.62 \%$ of sperm were stained only on the head, while just $19.3 \%$ showed certain reactivity in the tail. Once again, the incubation in capacitation conditions promoted threonine phosphorylation in the flagellum with $51.9 \%$ of cells exhibiting only a signal in the whole tail $(P<0.001)$, and a simultaneous decrease in the acrosomal and equatorial staining $(P<0.01$; Figs $5 \mathrm{C}$ and $8 \mathrm{C})$. The induction of the acrosome reaction with calcium ionophore also resulted in a loss of the acrosomal labeling $(P<0.001)$, with only $14.38 \%$ of sperm maintaining this localization (Fig. 8C). Most sperm showed phosphothreonine residues distributed over the
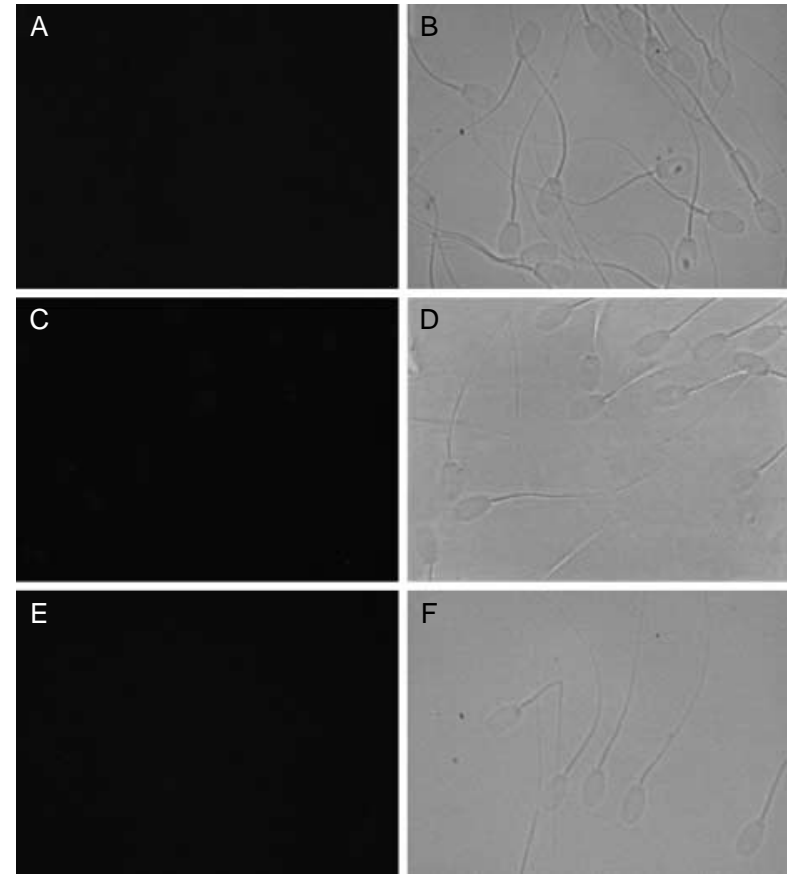

Figure 7 Negative controls using monoclonal anti-phosphotyrosine $(A, B)$, anti-phosphoserine (C, D), or anti-phosphothreonine (E, F) antibody pre-absorbed with phosphotyrosine $(12.5 \mathrm{mg} / \mathrm{ml})$, phosphoserine and phosphothreonine $(8.5 \mathrm{mg} / \mathrm{ml})$ respectively. Paired epifluorescent (A, C, E) and bright-field (B, D, F) pictures respectively are shown. Magnification $1000 \times$.

post-acrosome, with $(40.98 \%)$ or without signal at the flagellum, mainly the midpiece (Fig. 5E). These changes in phosphothreonine protein staining were confirmed by confocal microscopy (Fig. 5G-I).

The localization of sperm proteins phosphorylated at tyrosine, serine and threonine residues and their modifications due to in vitro capacitation and the acrosome reaction revealed by the avidin-biotin complex technique corroborated the previous findings (Fig. 9). These results were also highly specific because the incubation with only the secondary antibody (Fig. 6E) and replacing the antiserum with preimmune serum (Fig. 6F) abolished protein signaling.

\section{Discussion}

The involvement of the CAMP-PKA pathway in sperm capacitation (Visconti et al. 1997, Visconti \& Kopf 1998) and acrosome reaction (Breitbart \& Naor 1999, Garde \& Roldan 2000) has been reported as well as the modulation of both processes by intracellular signals associated to protein phosphorylation (Aitken et al. 1995, Burks et al. 1995, Baldi et al. 1996, Visconti \& Kopf 1998, Visconti et al. 2002, Naz \& Rajesh 2004, Liguori et al. 2005, O'Flaherty et al. 2006a). In addition, other Ser/Thr kinases such as MAPK also appear to play a role in capacitation (de Lamirande \& Gagnon 2002, O'Flaherty et al. 2006a, 2006b) and acrosome reaction 

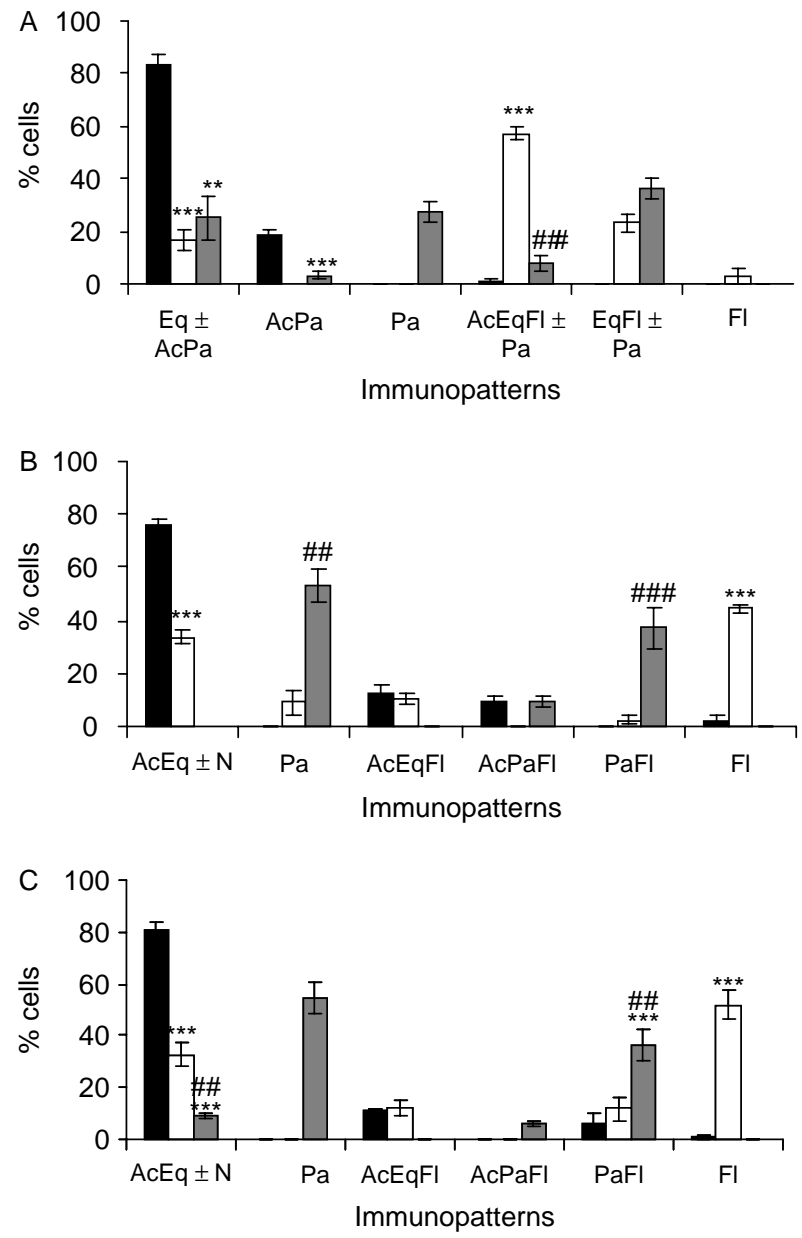

Figure 8 Percentage of ram spermatozoa showing different immunolocalization patterns of phosphotyrosine (A), phosphoserine (B) and phospothreonine $(\mathrm{C})$ proteins analyzed by indirect-immunofluorescence. Eq, equatorial region; Ac, acrosome; Pa, post-acrosome; N, neck; and Fl, flagellum. Black bars, control; white bars, capacitated; gray bars, acrosome-reacted samples. Mean values \pm s.E.M. $(n=3)$. Significant differences related to control samples: ${ }^{*} P<0.05$; ${ }^{* *} P<0.01$; ***P<0.001. Significant differences related to capacitated samples: ${ }^{\# \#} P<0.01,{ }^{\# \#} P<0.001$.

(Luconi et al. 1998, du Plessis et al. 2001, de Lamirande \& Gagnon 2002, Liguori et al. 2005), suggesting a complex regulation of these processes through different intracellular pathways (Liguori et al. 2005, O'Flaherty et al. 2006a, 2006b).

In previous studies (Perez-Pe et al. 2002, Grasa et al. 2006), we proved that protein tyrosine phosphorylation is associated to ram sperm capacitation, and that the CAMP-PKA pathway is at least partially implicated in this process. In this study, we found a certain degree of protein serine and threonine phosphorylation before incubating sperm in capacitating conditions (control samples, Fig. 2B and C). As the proportion of capacitated sperm in control samples was not very high (Fig. 1), this might have occurred either because phosphorylations started during the swim-up procedure, or because some
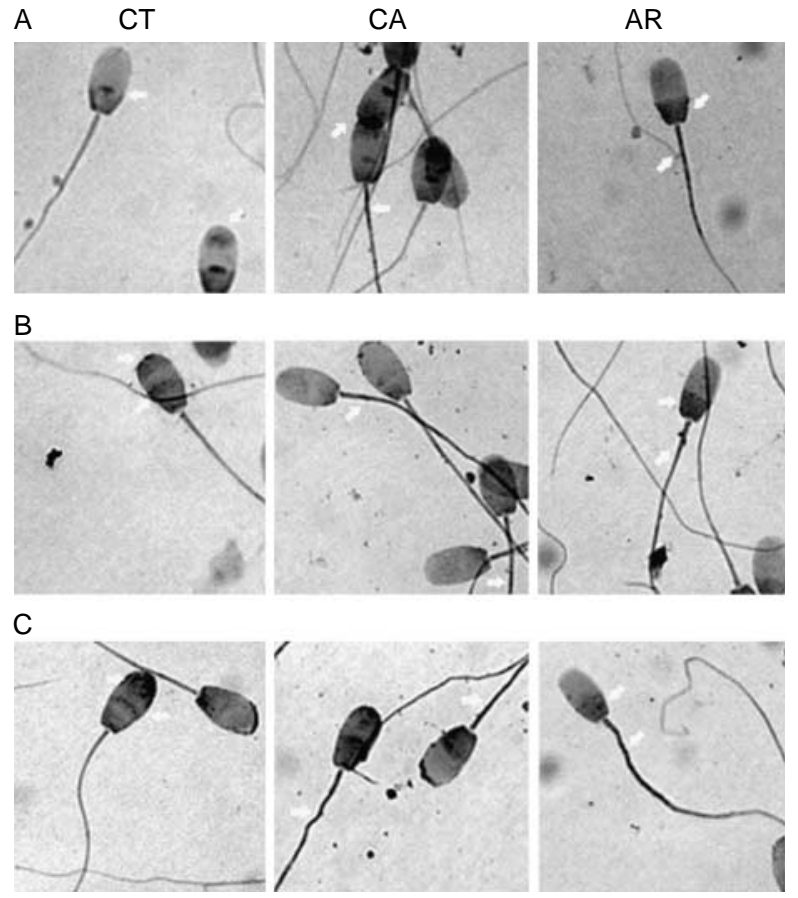

Figure 9 Immunocytochemical localization of phosphoproteins in control (CT), capacitated (CA) and acrosome-reacted (AR) ram spermatozoa using monoclonal anti-phospho tyrosine (A), serine (B) and threonine $(C)$ antibody. The arrows indicate different domains with specific phosphorylation. Magnification $1000 \times$.

proteins are constitutively phosphorylated in serine and/ or threonine residues, as already reported for tyrosine residues (Grasa et al. 2006). After incubating in capacitating conditions, we detected a quantitative increase in the intensity of several bands, which indicates that ram sperm capacitation is also associated with protein Ser/Thr phosphorylation (Fig. 2) as occurs in other species such as humans (Naz 1999, de Lamirande \& Gagnon 2002, O'Flaherty et al. 2004), hamsters (Jha \& Shivaji 2002b), boars (Harayama 2003, Harrison 2004) and mice (Jha et al. 2006). All controls carried out in this study proved signal specificity. The fact that after incubation with alkaline phosphatase, certain bands were still barely visible could well be because these bands correspond not to a monoester phosphate but a phosphodiester linkage on which alkaline phosphatase exhibits no activity, as already shown (Dennis et al. 2000).

It is noteworthy that the increase in serine-phosphorylated proteins (mainly 84-120 and 40-45 kDa molecular mass regions) partially coincides with the increase in threonine-phosphorylated proteins (84-120 and 40-70 kDa regions; Fig. $2 \mathrm{~B}$ and $\mathrm{C}$ ). In addition, the increase in phosphotyrosine protein signaling (40-120 and $<30 \mathrm{kDa}$ molecular mass) was linked to increased phosphothreonine protein labeling (the same molecular weight regions; Fig. 2A and $\mathrm{C}$ ). These observations would suggest that ram spermatozoa might possess dual 
specificity kinases that would phosphorylate in more than one residue, as already described in other mammalian species such as humans (Naz 1999, Thundathil et al. 2002, Ficarro et al. 2003), hamsters (Jha \& Shivaji $2002 b$ ) and boars (Harayama 2003, Harrison 2004).

Acrosomal exocytosis induced by calcium ionophore A23187 has been used in ram sperm to investigate the signaling pathways involved in this process (Roldan \& Fragio 1993, Garde \& Roldan 2000). In our study, the induction of the acrosome reaction by this compound resulted in a significant decrease in the phosphorylation signal, mainly of proteins whose phosphorylation increased during capacitation (Fig. 2). The fact that about $40 \%$ sperm maintained unreacted acrosomes might be explained by the high sperm heterogeneity that accounts for cells with a wide range of membrane properties and susceptibility. The decrease in the total phosphotyrosine content after inducing the acrosome reaction is consistent with previous observations in boar sperm (Kalab et al. 1998, Green \& Watson 2001), and indicates that dephosphorylation may be associated with $\mathrm{Ca}^{2+}$ influx during the acrosome reaction (Kalab et al. 1998, Baker et al. 2004). However, it may also be due to a loss of some phosphoproteins due to the high number of sperm that have reacted acrosomes.

Differences in the localization of phosphorylated proteins in sperm have been associated with different functions (Urner \& Sakkas 2003), and a specific sequence in the cellular immunolocalization of tyrosine phosphoproteins during capacitation and zona pellucida binding has been found in mice (Urner et al. 2001) and humans (Sakkas et al. 2003, Liu et al. 2006). Our results showed that, in control ram spermatozoa, tyrosinephosphorylated proteins are restricted to the head, distributed mainly at the equatorial region with some cells also displaying an acrosomal and/or post-acrosomal localization, and that in vitro capacitation promoted both tail and acrosome phosphorylation. Similarly, several studies have reported a preferential distribution of tyrosine phosphoproteins in the flagellum of capacitated sperm such as human (Carrera et al. 1996, Leclerc et al. 1997, Sakkas et al. 2003), monkey (Mahony \& Gwathmey 1999), mouse (Urner et al. 2001), hamster (Jha \& Shivaji 2002a) and stallion (Pommer et al. 2003). The situation of phosphorylated proteins at the principal piece of the flagellum has been related to motility hyperactivation and to the presence of A-kinase anchoring proteins (which anchor PKA) located in the fibrous sheath of the sperm flagellum in several species (Carrera et al. 1996, Mandal et al. 1999, Jha \& Shivaji 2002a, Pommer et al. 2003, Sakkas et al. 2003). Conversely, a capacitation-related redistribution of phosphotyrosine residues to the acrosome has been reported in humans (Naz et al. 1991), boars (Tardif et al. 2001, Dube et al. 2005), bulls (Cormier \& Bailey 2003) and buffalo (Roy \& Atreja 2008). Moreover, other studies have revealed that certain tyrosine phosphoproteins become localized to the sperm surface overlying the acrosome during capacitation suggesting a key role of these proteins in sperm-zona binding (Asquith et al. 2004, Piehler et al. 2006). Therefore, the distribution of phosphotyrosine residues and their modifications associated to ram sperm capacitation presented in this study might indicate a role of these proteins during capacitation and in acrosome reaction regulation.

In contrast to tyrosine-phosphorylated proteins, the studies carried out to date on serine and threonine phosphorylation are relatively scarce. The preferential localization over the sperm head (Figs 4 and 5) found in control samples changed during capacitation, which induced tail phosphorylation in a sequential manner. The phosphorylation pattern ranged from sperm showing reactivity at the neck and principal piece to sperm displaying phosphoproteins all along the flagellum, as previously reported for cAMP-dependent serine/threonine phosphorylation in boar sperm (Harayama 2003). Simultaneously, a decrease in the acrosomal content of serine/threonine phosphoproteins was achieved. It is noteworthy that the bright signal of serine and threonine residues on the acrosome became punctate after capacitation, which indicates a lower content of these proteins at this region. Similarly, a preferential localization of serine-/threonine-phosphorylated proteins over the tail regions has been reported in capacitated sperm of humans (Naz 1999, O'Flaherty et al. 2004), hamsters (Jha \& Shivaji 2002b) and mice (Jha et al. 2006). Moreover, serine/threonine phosphorylation appears to occur early during capacitation, as reported in boar for PKA-catalyzed phosphorylation (Harayama 2003, Harrison 2004) or in mouse proline-directed serine/ threonine phosphorylation (Jha et al. 2006), which would indicate that the activation of serine/threonine kinases is upstream of tyrosine phosphorylation.

Our data also showed that the induction of the acrosome reaction promoted the loss of phosphoprotein labeling on the acrosomal domain and the subsequent increase in the post-acrosomal region and flagellum (middle piece), which might suggest a key role for these proteins in further stages of sperm-oocyte interaction. The loss of the acrosomal localization could be related to masking, redistribution, dephosphorylation, or the loss of proteins involved in fusion membrane events as the number of sperm with reacted acrosomes is very high. Furthermore, the localization of phosphorylated proteins in the acrosome of capacitated sperm, together with its further loss after the acrosome reaction, could be related to the activation of certain proteins involved in this process (Dube et al. 2005). Similarly, as reported in several mammalian species, zona pellucida binding induced phosphorylation in the midpiece (Leyton \& Saling 1989, Flesch et al. 2001) and other tail regions (Urner et al. 2001, Sakkas et al. 2003). 
The results of immunofluorescence analysis were confirmed by immunocytochemistry and confocal microscopy, and allow us to postulate a subcellular localization of phosphorylated proteins in different cell compartments. Our data are consistent with those in a previous report in which we identified the presence of a seminal plasma protein in the ram sperm membrane (RSVP14, Fernandez-Juan et al. 2006), phosphorylated at serine and threonine residues, which undergoes a partial loss and redistribution during capacitation and acrosome reaction towards the post-acrosomal and equatorial regions (Barrios et al. 2005). The results of the present study support our previous suggestion that serine/ threonine phosphorylation may play an important role in sperm capacitation, since consolidation of phosphoproteins to specific domains of the head and tail may facilitate the acrosome reaction and egg penetration (Naz 1999). Moreover, the similar localization and the changes described for tyrosine-, serine- and threoninephosphorylated proteins indicates the activation of signal transduction pathways in specific sperm domains associated to specific functions, as already reported in boar sperm (Harayama 2003).

In conclusion, in vitro ram sperm capacitation and the acrosome reaction promoted changes in the content and subcellular localization of proteins phosphorylated at tyrosine, serine and threonine residues towards new domains involved in later stages of fertilization. These changes may have a physiological significance in consolidating certain phosphorylated proteins to specific sperm regions involved in acrosomal exocytosis and zona pellucida recognition, binding and penetration.

\section{Materials and Methods}

\section{Sperm preparation}

All experiments were performed using fresh ram spermatozoa. Semen was collected from eight mature Rasa Aragonesa rams using an artificial vagina. The rams, ranging from 2 to 4 years of age, were supplied by the National Association of Rasa Aragonesa Breeding (ANGRA), and were kept at the Faculty of Veterinary Medicine under uniform nutritional conditions.

The sires were kept apart and semen was collected every two days, in two successive matings each day (0830-0930 h). Under these conditions, and using second ejaculates, individual differences are very low, as we have already reported (Ollero et al. 1996), and pooled ejaculates provide a uniform, good quality sperm sample suitable for representative studies of ram semen.

A seminal plasma-free sperm population was obtained by a dextran/swim-up procedure (García-López et al. 1996) performed in a media devoid of $\mathrm{NaHCO}_{3}$ and $\mathrm{CaCl}_{2}$, (Grasa et al. 2004 , 2006). Control samples (not capacitated, NC) were taken immediately following swim-up procedure to process by immunoblotting and immunofluorescence.

\section{In vitro capacitation and acrosome reaction}

In vitro capacitation was performed by incubating the swim-up obtained samples $\left(2 \times 10^{8}\right.$ cells $\left./ \mathrm{ml}\right)$ in the presence of $25 \mathrm{mM}$ $\mathrm{NaHCO}_{3}, 3 \mathrm{mM} \mathrm{CaCl}_{2}$ and $5 \mathrm{mg} / \mathrm{ml}$ of BSA for $4 \mathrm{~h}$ at $39{ }^{\circ} \mathrm{C}$ in a humidified incubator with $5 \% \mathrm{CO}_{2}$ in air, obtaining capacitated samples (C).

Acrosome reaction was induced by the addition of $3 \mu \mathrm{M}$ calcium ionophore A23187 (Sigma Chemical Co.) in $0.3 \%$ DMSO, Sigma Chemical Co.) to previously capacitated sperm $\left(2 \times 10^{7}\right.$ cells $\left./ \mathrm{ml}\right)$ and further incubation at $39^{\circ} \mathrm{C}$ for $1 \mathrm{~h}(\mathrm{AR}$ samples, Marti et al. 2000). Control tubes had DMSO added but no ionophore, which was found to be without effect (data not shown).

\section{Evaluation of sperm samples}

Sperm concentration was calculated in duplicate using a Neubauer's chamber (Marienfeld, Germany).

Capacitation status was evaluated using the CTC assay in combination with EthD-1 staining, Molecular Probes Inc., Eugene, OR, USA), as previously described (Grasa et al. 2006). Three sperm populations, NC, capacitated (C) and AR cells, were estimated under epifluorescence illumination using a $\mathrm{V}$-2A filter. For treatment of results, only the live cells were taken into consideration.

\section{Extraction of proteins}

Aliquots of $0.5 \mathrm{ml}\left(10^{7}\right.$ cells) of $\mathrm{NC}, \mathrm{C}$ and $\mathrm{AR}$ samples were centrifuged in a microfuge at $7500 \mathrm{~g}$ for $5 \mathrm{~min}$ at room temperature, and the supernatant was discarded. The resulting sperm pellet was resuspended in $100 \mathrm{ml}$ extraction medium ( $2 \%$ SDS, $28 \%$ sucrose, $12.4 \mathrm{mM} \mathrm{N}, N, N, N^{\prime}$-tetramethylethylenediamine and $185 \mathrm{mM}$ Tris- $\mathrm{HCl}, \mathrm{pH}$ 6.8; Roldan \& Harrison 1988) and immediately incubated for $5 \mathrm{~min}$ at $100{ }^{\circ} \mathrm{C}$. After centrifugation at $7500 \mathrm{~g}$ for $5 \mathrm{~min}$, the supernatant was recovered and 2-mercaptoethanol and glycerol were added to a final concentration of 5 and $1 \%$ respectively. Finally, extracts were incubated at $100{ }^{\circ} \mathrm{C}$ for $5 \mathrm{~min}$ and then stored at $-20^{\circ} \mathrm{C}$ until required. Prior to the addition of 2-mercaptoethanol, the concentration of extracted proteins was measured using the Micro BCA Protein Assay Reagent kit (Pierce, Rockford, IL, USA).

\section{SDS-PAGE and western blot analysis}

Solubilized proteins were separated by electrophoresis on 4-22.5\% (w/v) SDS-PAGE gels (Laemmli 1970) and electrotransferred onto Immobilon-P (Millipore, Bedford, MA, USA) as previously described (Perez-Pe et al. 2002). Non-specific binding sites on membranes were blocked with 5\% BSA (w/v) in Tris-buffered saline $(10 \mathrm{mM}$ Tris- $\mathrm{HCl}, \mathrm{pH} 8,120 \mathrm{mM} \mathrm{NaCl}$ and $0.05 \%$ Tween 20 ) for $1 \mathrm{~h}$. The phosphoproteins were immunodetected by incubating with the primary mouse monoclonal anti-phosphotyrosine (1:2000), phosphoserine (1:4000), or phosphothreonine $(1: 4000)$ antibody (PT-66, PSR-45 and PTR-8 respectively, Sigma Chemical Co.) for $3 \mathrm{~h}$ 
at room temperature. After several washes in Tris-buffered saline, the membranes were incubated for $1 \mathrm{~h}$ with a secondary goat anti-mouse alkaline phosphatase-conjugated IgG (1:4000; Sigma Chemical Co.). Thereafter, phosphorylated proteins were visualized by incubation with a substrate mixture of nitro blue tetrazolium and 5-bromo-4-chloro-3-indolyl phosphate $(0.33 \mathrm{mg} / \mathrm{ml}$ in dimethyl formamide) in $0.2 \mathrm{M}$ Tris, $5 \mathrm{mM}$ $\mathrm{MgCl}_{2}$ and $\mathrm{NaCl} 0.1 \mathrm{M}, \mathrm{pH}$ 9.6. Finally, the membranes were washed with distilled water, dried, and scanned.

Western blot images were analyzed using Scion Image software (Scion Co., Frederick, Ma, USA) to quantified changes in the phosphorylated proteins. The phosphorylation signal was evaluated as volume (area $X$ intensity), and results are shown as a percentage relative to the total phosphorylation signal obtained in each case.

The specificity of each antibody was proved by incubating each primary antibody with the competing agent phosphotyrosine, phosphoserine and phosphothreonine respectively, overnight at $4{ }^{\circ} \mathrm{C}$. Different concentrations of the three phosphoamino acids $(25,50,100,500$ and $1000 \mu \mathrm{g} / \mathrm{ml})$ were assayed.

In addition, to prove that these proteins are phosphorylated, sperm protein samples $(100 \mu \mathrm{g})$ were incubated with $23 \mathrm{U}$ alkaline phosphatase, $14 \mathrm{mM} \mathrm{NaCl}, 0.5 \mathrm{mM} \mathrm{MgCl}_{2}, 0.5 \mathrm{mM}$ $\mathrm{ZnCl}_{2}$ and $140 \mu \mathrm{M}$ triethanolamine, overnight a $37^{\circ} \mathrm{C}$.

\section{Indirect immunofluorescence}

The localization of proteins phosphorylated at tyrosine, serine and threonine residues of NC, C and AR samples was investigated by indirect immunofluorescence. Sperm samples were washed with PBS ( $\mathrm{pH} 7.2$ ) and fixed for $30 \mathrm{~min}$ in $4 \%$ of paraformaldehyde. After fixation and washing, cell samples were allowed to settle on poly-L-lysine-coated slides and permeabilized by methanol for $15 \mathrm{~min}$. The slides were then washed twice with PBS, and non-specific binding sites were blocked with $5 \%$ BSA in PBS for $1 \mathrm{~h}$ at $37{ }^{\circ} \mathrm{C}$ in a humid chamber. After blocking, the slides were washed three times with PBS and anti-phosphotyrosine (PT-66), anti-phosphoserine (PSR-45), or anti-phosphothreonine (PTR-8) mouse antibodies (Sigma Chemical Co.) 1:200, 1:400, 1:400 in PBS with $0.5 \%$ BSA respectively were added. The preparations were incubated for $2 \mathrm{~h}$ at $37^{\circ} \mathrm{C}$ in the wet chamber, washed three times and incubated again with a fluorescein isothiocyanate (FITC)-conjugated chicken anti-mouse IgG (Molecular Probes, Leiden, The Netherlands; 1:500 diluted in PBS with $0.5 \% \mathrm{BSA}$ ) for $1.5 \mathrm{~h}$ at $37{ }^{\circ} \mathrm{C}$ in darkness. The slides were rinsed with $\mathrm{PBS}$ and mixed with $5 \mu \mathrm{l} 0.22 \mathrm{M}$ triethylenediamine (DABCO, Sigma Chemical Co.) in glycerol:PBS (9:1) in order to enhance and preserve cell fluorescence. Finally, the preparations were covered with cover slips, sealed with colorless enamel, and visualized under a Nikon Eclipse E400 microscope (Nikon, Tokyo, Japan) under epifluorescence illumination using a B-2A filter. At least 200 cells per sample were evaluated and the percentage of cells displaying positive fluorescence was scored. Negative controls were performed by processing slides with either the secondary antibody alone, or with mouse preimmune serum (diluted with PBS 1:100) instead of the primary antibody. In addition, another control using each primary antibody (anti-phosphotyrosine 1:200, anti-phosphoserine 1:400, or anti-phosphothreonine 1:400 in PBS with $0.5 \%$ BSA) pre-incubated with phosphotyrosine $(12.5 \mathrm{mg} / \mathrm{ml})$ phosphoserine $(8.5 \mathrm{mg} / \mathrm{ml})$ and phosphothreonine $(8.5 \mathrm{mg} / \mathrm{ml})$, overnight at $4{ }^{\circ} \mathrm{C}$, was carried out. Images were obtained using a microscope digital camera system (Sony 2CCD Color Video Camera and Sony Digital Still Recorder) and saved and edited with Visilog 5.1 Software (Microptic, Barcelona, Spain).

The localization patterns of phosphoproteins observed by immunofluorescence were confirmed by three-dimensional confocal microscopy analysis, performed with a confocal microscope (Zeiss 310) using LSM 3.95 software. Individual cells were observed within 10 successive focal planes separated $0.1-0.2 \mu \mathrm{m}$.

\section{Immunocytochemical technique}

The spermatozoa were exposed to immunocytochemical staining by using an avidin-biotin-peroxidase technique (Vector, Los Angeles, CA, USA). Sperm samples were smeared onto poly-L-lysine-coated slides and fixed in methanol as described above. After rehydration in $\mathrm{PBS}$ pH 7.2, endogenous peroxidase was inactivated with $1.7 \%$ hydrogen peroxide in $100 \%$ ethanol for $30 \mathrm{~min}$. Subsequently, they were washed with PBS pH 7.2, and then incubated in normal horse serum (blocking reagent; Vector) for $45 \mathrm{~min}$, followed by incubation for $2 \mathrm{~h} 30 \mathrm{~min}$ with the specific antiserum (primary antibody) as described for indirect immunofluorescence. After washing, the slides were incubated with biotinylated anti-mouse antiserum for $40 \mathrm{~min}$. An avidin-biotin-peroxidase complex was then applied for $45 \mathrm{~min}$. The binding sites of the primary antibodies were visualized by diaminobenzidine $(\mathrm{DAB})$ and hydrogen peroxide solution $(20 \mathrm{mg} \mathrm{DAB}$ in $100 \mathrm{ml}$ of $0.05 \mathrm{M}$ Tris- $\mathrm{HCl}$ buffer, pH 7.6, containing $0.005 \% \mathrm{H}_{2} \mathrm{O}_{2}$ ) for $5 \mathrm{~min}$. As negative controls, samples were incubated with preimmune serum instead of the primary antibody, with the remaining procedure being the same. In these conditions, no reactivity was found. Likewise, slides were processed with the secondary antibody alone as another negative control. The images obtained were taken using the same microscope digital camera system and software as for immunofluorescence.

\section{Statistical analysis}

Results are shown as mean \pm S.E.M. of the number of samples indicated in each case. ANOVA was performed to determine whether there were significant differences between samples, and post hoc comparisons were made using Tukey's test. Software used was GraphPad InStat (San Diego, CA, USA).

\section{Declaration of interest}

The authors declare that there is no conflict of interest that could be perceived as prejudicing the impartiality of the research reported. 


\section{Funding}

Supported by grants CICYT-FEDER AGL 2005-02614, CICYTFEDER AGL 2007-061229, and DGA-A26/2007.

\section{Acknowledgements}

The authors thank ANGRA for supplying the sires, M Cebrian for the artwork, and S Morales for the collection of semen samples.

\section{References}

Aitken RJ, Paterson M, Fisher H, Buckingham DW \& van Duin M 1995 Redox regulation of tyrosine phosphorylation in human spermatozoa and its role in the control of human sperm function. Journal of Cell Science 108 2017-2025.

Asquith KL, Baleato RM, McLaughlin EA, Nixon B \& Aitken RJ 2004 Tyrosine phosphorylation activates surface chaperones facilitating sperm-zona recognition. Journal of Cell Science 117 3645-3657.

Baker MA, Hetherington L, Ecroyd H, Roman SD \& Aitken RJ 2004 Analysis of the mechanism by which calcium negatively regulates the tyrosine phosphorylation cascade associated with sperm capacitation. Journal of Cell Science 117 211-222.

Baldi E, Luconi M, Bonaccorsi L, Krausz C \& Forti G 1996 Human sperm activation during capacitation and acrosome reaction: role of calcium, protein phosphorylation and lipid remodelling pathways. Frontiers in Bioscience 1 189-205.

Barrios B, Fernandez-Juan M, Muino-Blanco T \& Cebrian-Perez JA 2005 Immunocytochemical localization and biochemical characterization of two seminal plasma proteins that protect ram spermatozoa against cold shock. Journal of Andrology 26 539-549.

Breitbart H \& Naor Z 1999 Protein kinases in mammalian sperm capacitation and the acrosome reaction. Reviews of Reproduction 4 151-159.

Burks DJ, Carballada R, Moore HD \& Saling PM 1995 Interaction of a tyrosine kinase from human sperm with the zona pellucida at fertilization. Science 269 83-86.

Carrera A, Moos J, Ning XP, Gerton GL, Tesarik J, Kopf GS \& Moss SB 1996 Regulation of protein tyrosine phosphorylation in human sperm by a calcium/calmodulin-dependent mechanism: identification of A kinase anchor proteins as major substrates for tyrosine phosphorylation. Developmental Biology 180 284-296.

Cormier N \& Bailey JL 2003 A differential mechanism is involved during heparin- and cryopreservation-induced capacitation of bovine spermatozoa. Biology of Reproduction 69 177-185.

Dennis AL, Puskas M, Stasaitis S \& Sandwick RK 2000 The formation of a 1-5 phosphodiester linkage in the spontaneous breakdown of 5-phosphoribosyl-alpha-1-pyrophosphate. Journal of Inorganic Biochemistry 81 73-80.

Dube C, Leclerc P, Baba T, Reyes-Moreno C \& Bailey JL 2005 The proacrosin binding protein, sp32, is tyrosine phosphorylated during capacitation of pig sperm. Journal of Andrology 26 519-528.

Fernandez-Juan M, Gallego M, Barrios B, Osada J, Cebrian-Perez JA \& Muino-Blanco T 2006 Immunohistochemical localization of spermpreserving proteins in the ram reproductive tract. Journal of Andrology 27 588-595.

Ficarro S, Chertihin O, Westbrook VA, White F, Jayes F, Kalab P, Marto JA, Shabanowitz J, Herr JC, Hunt DF et al. 2003 Phosphoproteome analysis of capacitated human sperm. Evidence of tyrosine phosphorylation of a kinase-anchoring protein 3 and valosin-containing protein/p97 during capacitation. Journal of Biological Chemistry 278 11579-11589.

Flesch FM, Wijnand E, van de Lest CH, Colenbrander B, van Golde LM \& Gadella BM 2001 Capacitation dependent activation of tyrosine phosphorylation generates two sperm head plasma membrane proteins with high primary binding affinity for the zona pellucida. Molecular Reproduction and Development 60 107-115.
García-López N, Ollero M, Muiño-Blanco T \& Cebrián-Pérez JA 1996 A dextran swim-up procedure for separation of highly motile and viable ram spermatozoa from seminal plasma. Theriogenology 46 141-151.

Garde J \& Roldan ER 2000 Stimulation of $\mathrm{Ca}(2+)$-dependent exocytosis of the sperm acrosome by cAMP acting downstream of phospholipase A2. Journal of Reproduction and Fertility 118 57-68.

Grasa P, Perez-Pe R, Baguena O, Forcada F, Abecia A, Cebrian-Perez JA \& Muino-Blanco T 2004 Ram sperm selection by a dextran/swim-up procedure increases fertilization rates following intrauterine insemination in superovulated ewes. Journal of Andrology 25 982-990.

Grasa P, Cebrian-Perez JA \& Muino-Blanco T 2006 Signal transduction mechanisms involved in in vitro ram sperm capacitation. Reproduction 132 721-732.

Green CE \& Watson PF 2001 Comparison of the capacitation-like state of cooled boar spermatozoa with true capacitation. Reproduction 122 889-898.

Harayama H 2003 Viability and protein phosphorylation patterns of boar spermatozoa agglutinated by treatment with a cell-permeable cyclic adenosine $3^{\prime}, 5^{\prime}$-monophosphate analog. Journal of Andrology 24 831-842.

Harrison RA 2004 Rapid PKA-catalysed phosphorylation of boar sperm proteins induced by the capacitating agent bicarbonate. Molecular Reproduction and Development 67 337-352.

Jha KN \& Shivaji S 2002a Identification of the major tyrosine phosphorylated protein of capacitated hamster spermatozoa as a homologue of mammalian sperm a kinase anchoring protein. Molecular Reproduction and Development $61258-270$.

Jha KN \& Shivaji S 2002b Protein serine and threonine phosphorylation, hyperactivation and acrosome reaction in in vitro capacitated hamster spermatozoa. Molecular Reproduction and Development 63 119-130.

Jha KN, Salicioni AM, Arcelay E, Chertihin O, Kumari S, Herr JC \& Visconti PE 2006 Evidence for the involvement of proline-directed serine/threonine phosphorylation in sperm capacitation. Molecular Human Reproduction 12 781-789.

Johnson LN \& Barford D 1993 The effects of phosphorylation on the structure and function of proteins. Annual Review of Biophysics and Biomolecular Structure 22 199-232.

Johnson LN \& O'Reilly M 1996 Control by phosphorylation. Current Opinion in Structural Biology 6 762-769.

Kalab P, Peknicova J, Geussova G \& Moos J 1998 Regulation of protein tyrosine phosphorylation in boar sperm through a cAMP-dependent pathway. Molecular Reproduction and Development 51 304-314.

Laemmli UK 1970 Cleavage of structural proteins during the assembly of the head of bacteriophage T4. Nature 227 680-685.

de Lamirande E \& Gagnon C 2002 The extracellular signal-regulated kinase (ERK) pathway is involved in human sperm function and modulated by the superoxide anion. Molecular Human Reproduction 8 124-135.

Leclerc P, de Lamirande E \& Gagnon C 1997 Regulation of protein-tyrosine phosphorylation and human sperm capacitation by reactive oxygen derivatives. Free Radical Biology \& Medicine 22 643-656.

Lewis B \& Aitken RJ 2001 A redox-regulated tyrosine phosphorylation cascade in rat spermatozoa. Journal of Andrology 22 611-622.

Leyton L \& Saling P $198995 \mathrm{kd}$ sperm proteins bind ZP3 and serve as tyrosine kinase substrates in response to zona binding. Cell $\mathbf{5 7}$ 1123-1130.

Liguori L, de Lamirande E, Minelli A \& Gagnon C 2005 Various protein kinases regulate human sperm acrosome reaction and the associated phosphorylation of Tyr residues and of the Thr-Glu-Tyr motif. Molecular Human Reproduction 11 211-221.

Liu DY, Clarke GN \& Baker HW 2006 Tyrosine phosphorylation on capacitated human sperm tail detected by immunofluorescence correlates strongly with sperm-zona pellucida (ZP) binding but not with the ZP-induced acrosome reaction. Human Reproduction 21 1002-1008.

Luconi M, Barni T, Vannelli GB, Krausz C, Marra F, Benedetti PA, Evangelista V, Francavilla S, Properzi G, Forti G et al. 1998 Extracellular signal-regulated kinases modulate capacitation of human spermatozoa. Biology of Reproduction 58 1476-1489.

Mahony MC \& Gwathmey T 1999 Protein tyrosine phosphorylation during hyperactivated motility of cynomolgus monkey (Macaca fascicularis) spermatozoa. Biology of Reproduction 60 1239-1243. 
Maiti A, Mishra KP \& Majumder GC 2004 Identification of goat sperm ectocyclic AMP independent protein kinase substrate localized on sperm outer surface. Journal of Cellular Biochemistry 92 164-177.

Mandal A, Naaby-Hansen S, Wolkowicz MJ, Klotz K, Shetty J, Retief JD, Coonrod SA, Kinter M, Sherman N, Cesar F et al. 1999 FSP95, a testisspecific 95-kilodalton fibrous sheath antigen that undergoes tyrosine phosphorylation in capacitated human spermatozoa. Biology of Reproduction 61 1184-1197.

Marti JI, Cebrian-Perez JA \& Muino-Blanco T 2000 Assessment of the acrosomal status of ram spermatozoa by RCA lectin-binding and partition in an aqueous two-phase system. Journal of Andrology 21 541-548.

Moseley FL, Jha KN, Bjorndahl L, Brewis IA, Publicover SJ, Barratt CL \& Lefievre L 2005 Protein tyrosine phosphorylation, hyperactivation and progesterone-induced acrosome reaction are enhanced in IVF media: an effect that is not associated with an increase in protein kinase A activation. Molecular Human Reproduction 11 523-529.

Nassar A, Mahony M, Morshedi M, Lin MH, Srisombut C \& Oehninger S 1999 Modulation of sperm tail protein tyrosine phosphorylation by pentoxifylline and its correlation with hyperactivated motility. Fertility and Sterility 71 919-923.

Naz RK 1999 Involvement of protein serine and threonine phosphorylation in human sperm capacitation. Biology of Reproduction 60 1402-1409.

Naz RK \& Rajesh PB 2004 Role of tyrosine phosphorylation in sperm capacitation/acrosome reaction. Reproductive Biology and Endocrinology 275.

Naz RK, Ahmad K \& Kumar R 1991 Role of membrane phosphotyrosine proteins in human spermatozoal function. Journal of Cell Science $\mathbf{9 9}$ 157-165.

O'Flaherty C, de Lamirande E \& Gagnon C 2004 Phosphorylation of the arginine-X-X-(serine/threonine) motif in human sperm proteins during capacitation: modulation and protein kinase A dependency. Molecular Human Reproduction 10 355-363.

O'Flaherty C, de Lamirande E \& Gagnon C 2006a Reactive oxygen species modulate independent protein phosphorylation pathways during human sperm capacitation. Free Radical Biology \& Medicine 40 1045-1055.

O'Flaherty C, de Lamirande E \& Gagnon C 2006b Positive role of reactive oxygen species in mammalian sperm capacitation: triggering and modulation of phosphorylation events. Free Radical Biology \& Medicine 41 528-540.

Ollero M, Muino-Blanco T, Lopez-Perez MJ \& Cebrian-Perez JA 1996 Viability of ram spermatozoa in relation to the abstinence period and successive ejaculations. International Journal of Andrology 19 287-292.

Perez-Pe R, Grasa P, Fernandez-Juan M, Peleato ML, Cebrian-Perez JA \& Muino-Blanco T 2002 Seminal plasma proteins reduce protein tyrosine phosphorylation in the plasma membrane of cold-shocked ram spermatozoa. Molecular Reproduction and Development 61 226-233.

Petrunkina AM, Friedrich J, Drommer W, Bicker G, Waberski D \& TopferPetersen E 2001 Kinetic characterization of the changes in protein tyrosine phosphorylation of membranes, cytosolic $\mathrm{Ca}^{2+}$ concentration and viability in boar sperm populations selected by binding to oviductal epithelial cells. Reproduction 122 469-480.

Petrunkina AM, Simon K, Gunzel-Apel AR \& Topfer-Petersen E 2003 Specific order in the appearance of protein tyrosine phosphorylation patterns is functionally coordinated with dog sperm hyperactivation and capacitation. Journal of Andrology 24 423-437.

Piehler E, Petrunkina AM, Ekhlasi-Hundrieser M \& Topfer-Petersen E 2006 Dynamic quantification of the tyrosine phosphorylation of the sperm surface proteins during capacitation. Cytometry. Part A 69 1062-1070.

du Plessis SS, Page C \& Franken DR 2001 The zona pellucida-induced acrosome reaction of human spermatozoa involves extracellular signalregulated kinase activation. Andrologia 33 337-342.
Pommer AC, Rutllant J \& Meyers S 2003 Phosphorylation of protein tyrosine residues in fresh and cryopreserved stallion spermatozoa under capacitating conditions. Biology of Reproduction $\mathbf{6 8}$ $1208-1214$.

Roldan ER \& Fragio C 1993 Phospholipase A2 activation and subsequent exocytosis in the $\mathrm{Ca}^{2+}$ /ionophore-induced acrosome reaction of ram spermatozoa. Journal of Biological Chemistry 268 13962-13970.

Roldan ER \& Harrison RA 1988 Absence of active protein kinase C in ram spermatozoa. Biochemical and Biophysical Research Communications 155 901-906.

Roy SC \& Atreja SK 2008 Tyrosine phosphorylation of a 38-kDa capacitation-associated buffalo (Bubalus bubalis) sperm protein is induced by L-arginine and regulated through a CAMP/PKA-independent pathway. International Journal of Andrology 31 12-24.

Sakkas D, Leppens-Luisier G, Lucas H, Chardonnens D, Campana A, Franken DR \& Urner F 2003 Localization of tyrosine phosphorylated proteins in human sperm and relation to capacitation and zona pellucida binding. Biology of Reproduction 68 1463-1469.

Si Y \& Okuno M 1999 Role of tyrosine phosphorylation of flagellar proteins in hamster sperm hyperactivation. Biology of Reproduction $\mathbf{6 1}$ 240-246.

Suarez SS 1996 Hyperactivated motility in sperm. Journal of Andrology 17 331-335.

Tardif S, Dube C, Chevalier S \& Bailey JL 2001 Capacitation is associated with tyrosine phosphorylation and tyrosine kinase-like activity of pig sperm proteins. Biology of Reproduction 65 784-792.

Thundathil J, de Lamirande E \& Gagnon C 2002 Different signal transduction pathways are involved during human sperm capacitation induced by biological and pharmacological agents. Molecular Human Reproduction 8 811-816.

Ullrich A \& Schlessinger J 1990 Signal transduction by receptors with tyrosine kinase activity. Cell 61 203-212.

Urner F \& Sakkas D 2003 Protein phosphorylation in mammalian spermatozoa. Reproduction 125 17-26.

Urner F, Leppens-Luisier G \& Sakkas D 2001 Protein tyrosine phosphorylation in sperm during gamete interaction in the mouse: the influence of glucose. Biology of Reproduction 64 1350-1357.

Visconti PE \& Kopf GS 1998 Regulation of protein phosphorylation during sperm capacitation. Biology of Reproduction 59 1-6.

Visconti PE, Johnson LR, Oyaski M, Fornes M, Moss SB, Gerton GL \& Kopf GS 1997 Regulation, localization, and anchoring of protein kinase A subunits during mouse sperm capacitation. Developmental Biology 192 351-363.

Visconti PE, Westbrook VA, Chertihin O, Demarco I, Sleight S \& Diekman AB 2002 Novel signaling pathways involved in sperm acquisition of fertilizing capacity. Journal of Reproductive Immunology 53 133-150.

Wera S \& Hemmings BA 1995 Serine/threonine protein phosphatases. Biochemical Journal 311 17-29.

Yanagimachi R 1994 Mammalian fertilization. In The Physiology of Reproduction, pp 189-317. Eds E Knobil \& JD Neill. New York: Raven Press Ltd.

Received 25 June 2008

First decision 4 August 2008

Revised manuscript received 30 December 2008

Accepted 16 January 2009 